\title{
PERLINDUNGAN HUKUM KONSUMEN ATAS KESAMAAN BUNYI MEREK TERHADAP BARANG YANG TIDAK SEJENIS*
}

\author{
Evelyn Larissa Florentia Wijaya \\ Fakultas Hukum, Universitas Surabaya, \\ Gajah Mada No. 38 Ponorogo, Jawa Timur \\ e-mail : evelynwijaya72@gmail.com
}

\begin{abstract}
The practical purpose of the article is to find out whether consumers get legal protection if something goes wrong in choosing a product that has similar terms but different classification of types. The research is juridical-normative. With regard to the case of MICROCIDE (pharmaceutical preparations) and MICROZID (disinfectant), abviously the isues are different from trademark infringement in general. The use of different terminologies will possible to make consumers to be wrong in choosing the products which can cause a danger when it is consumed. There is remain legal vacuum in the absence of implementing regulations that regulate the same brand in principle for goods that are not of the same type so that consumer' rights cannot be fulfilled.
\end{abstract}

Keywords : Consumer Legal Protection; Legal Vacuum.

\section{Abstrak}

Tujuan praktis dari penulisan jurnal ini adalah untuk mengetahui apakah konsumen mendapatkan perlindungan hukum apabila terjadi salah dalam memilih produk yang memiliki kemiripan penyebutan namun berbeda klasifikasi jenis barangnya. Metode penelitian yang digunakan adalah yuridis normatif. Terkait kasus MICROCIDE (zat sediaan farmasi) dan MIKROZID (desinfektan) ini berbeda dengan pelanggaran merek pada umumnya. Persamaan penyebutan dan pengucapan ini dimungkinkan konsumen menjadi salah dalam memilih produk yang dibutuhkan dan dapat menimbulkan bahaya saat terkonsumsi. Masih adanya kekosongan hukum yakni belum adanya peraturan pelaksana yang mengatur merek yang sama pada pokoknya untuk barang yang tidak sejenis sehingga hak konsumen menjadi tidak dapat terpenuhi.

Kata Kunci: Perlindungan Hukum Konsumen; Kekosongan Hukum.

\footnotetext{
* Naskah diterima: 4 Agustus 2019, direvisi: 18 Januari 2020, disetujui untuk terbit: 26 Maret 2019 Doi: $10.3376 /$ jch.v5i2.187
} 


\section{PENDAHULUAN}

Perlindungan konsumen merupakan bagian yang tidak terpisahkan dari kegiatan bisnis yang sehat. Dalam kegiatan bisnis yang sehat terdapat keseimbangan perlindungan hukum antara konsumen dan produsen. Tidak adanya perlindungan yang seimbang menyebabkan konsumen pada posisi yang lemah. Kerugian-kerugian yang dialami oleh konsumen dapat timbul sebagai akibat dari adanya hubungan hukum perjanjian antara produsen dan konsumen, maupun akibat dari adanya perbuatan melanggar hukum yang dilakukan oleh produsen.

Hukum perlindungan konsumen dewasa ini mendapat cukup perhatian karena menyangkut aturan-aturan guna menjamin peningkatan kesejahteraan masyarakat serta kepastian atas hak-hak masyarakat, dalam hal ini bukan saja masyarakat selaku konsumen saja yang mendapat perlindungan, tetapi masyarakat selaku produsen. Pemerintah berperan mengatur, mengawasi dan mengontrol, sehingga tercipta sistem yang kondusif berkaitan satu dengan yang lain.

Terkait dengan masalah ini, ada dua produk yang diduga bersaing satu sama lain. Tujuan dari adanya kebijakan persaingan usaha adalah untuk memastikan bahwa kompetisi atau persaingan pasar tidak terbatasi dalam cara-cara yang membahayakan konsumen. (Permatasari, 2008). Keduanya produk ini mempunyai nama yang hampir sama dan mirip dalam penyebutannya yaitu MICROCIDE dan MICROZID. Padahal kedua merek tersebut sangat berbeda, penekanan perbedaan dari kedua merek tersebut adalah terkait dengan huruf " $S$ " dan "Z". MICROCIDE adalah zat kimia untuk sediaan farmasi dan MIKROZID adalah desinfektan (bahan kimia yang menjadi racun bila terminum oleh manusia).

Perlu diketahui bahwa, Permohonan Kasasi MICROCIDE ditolak oleh Mahkamah Agung berdasarkan Putusan Mahkamah Agung Nomor 653K/Pdt.SusHKI/2014 tanggal 27 Maret 2015. Sebagai dasar pertimbangannya bahwa Merek MICROCIDE tidak memiliki persamaan pada pokoknya atau keseluruhan dengan merek MIKROZID. Putusan MA tersebut berdasar pada belum adanya Peraturan Pelaksana atas pelanggaran merek yang sama pada pokoknya untuk barang yang tidak sejenis sebagaimana tertuang dalam Pasal 21 UU Merek yang menentukan sebagai berikut:

(1) Permohonan ditolak jika Merek tersebut mempunyai persamaan pada pokoknya atau keseluruhannya dengan:

a. Merek terdaftar milik pihak lain atau dimohonkan lebih dahulu oleh pihak lain untuk barang dan/atau jasa sejenis;

b. Merek terkenal milik pihak lain untuk barang dan/atau jasa sejenis;

c. Merek terkenal milik pihak lain untuk barang dan/atau jasa tidak sejenis yang memenuhi persyaratan tertentu; atau

d. Indikasi Geografis terdaftar.

Belum adanya Peraturan Pelaksana tersebut dapat mengakibatkan Pengguna 
Evelyn Larissa Florentia Wijaya: Perlindungan Hukum Konsumen Atas Kesamaan...

Merek yang sama pada pokoknya untuk barang yang tidak sejenis dapat merugikan Pemilik Merek dan Masyarakat sebagai Konsumen, Pemilik Merek akan dirugikan karena pemboncengan merek yang sudah terkenal dan masyarakat konsumen akan terkecoh atas keberadaan merek yang sama pada pokoknya tersebut tetapi untuk barang yang tidak sejenis.

Pengertian perlindungan konsumen adalah : tempat berlindung, hal (perbuatan dan sebagainya), memperlindungi (Purwadarninta, n.d.). Terkait hal tersebut (Endang Sri Wahyuni, n.d.) mengatakan : "Perlindungan konsumen merupakan suatu perbuatan untuk memberikan suatu perlindungan konsumen yaitu setiap orang pemakai barang dan/atau jasa yang tersedia dalam masyarakat, baik bagi kepentingan diri sendiri, keluarga, orang lain maupun makhluk hidup lain dan tidak untuk diperdagangkan. Sedangkan Pengertian Perlindungan Konsumen menurut (Ahmadi Miru, n.d.) mengatakan: "Perlindungan hukum bagi konsumen merupakan hal penting dalam menjaga keseimbangan hubungan antara produsen dan konsumen, sehingga perlu adanya prinsip-prinsip perlindungan hukum bagi konsumen yang dapat menjadi acuan dalam memberikan perlindungan kepada konsumen".

Terkait dengan perlindungan terhadap konsumen di dalam UUPK khususnya pada Pasal 4 huruf (b) dan (c) menentukan bahwa:

b. Hak untuk memilih barang dan/atau jasa serta mendapatkan barang dan/atau jasa tersebut sesuai dengan nilai tukar dan kondisi serta jaminan yang dijanjikan ;

c. Hak atas informasi yang benar, jelas dan jujur mengenai kondisi dan jaminan barang dan/atau jasa.

Permasalahan yang dihadapi konsumen tidak sekedar bagaimana memilih barang tetapi jauh lebih kompleks dari itu yang menyangkut pada kesadaran semua pihak, baik konsumen itu sendiri, pengusaha maupun pemerintah tentang pentingnya perlindungan konsumen. Pengusaha harus menghargai hak-hak konsumen, mengikuti standar yang berlaku, dengan harga yang sesuai. Tujuan penyelenggaraan, pengembangan dan pengaturan perlindungan konsumen adalah untuk meningkatkan martabat dan kesadaran konsumen dan secara tidak langsung mendorong pelaku usaha dalam menyelenggarakan kegiatan usahanya dengan penuh rasa tanggung jawab. Perlu disadari bahwa konsumen mempunyai hak yang dilindungi oleh Undang-Undang Perlindungan konsumen.

Hak konsumen yang diabaikan oleh pelaku usaha perlu dicermati secara saksama. Pada era globalisasi dan perdagangan bebas saat ini, banyak bermunculan berbagai macam produk barang/pelayanan jasa yang dipasarkan kepada konsumen di tanah air, baik melalui promosi, iklan maupun penawaran barang secara langsung. Jika tidak berhati-hati dalam memilih produk barang/jasa yang diinginkan, konsumen hanya akan menjadi objek eksploitasi dari pelaku usaha yang tidak bertanggung 
jawab. Tanpa disadari, konsumen menerima begitu saja barang/jasa yang di konsumsinya.

Faktanya, tidak dapat di pungkiri kebenarannya bahwa belum adanya Peraturan Pelaksana tersebut dapat mengakibatkan Penggunaan Merek yang sama pada pokoknya untuk barang yang tidak sejenis dapat merugikan Pemilik Merek dan Masyarakat sebagai Konsumen. Pemilik Merek juga dirugikan karena pemboncengan merek yang sudah terkenal dan masyarakat konsumen akan terkecoh atas keberadaan merek yang sama pada pokoknya tersebut untuk barang yang tidak sejenis.

Pelaku usaha MIKROZID telah menggunakan merek yang sama pada pokoknya dengan Pelaku usaha MICROCIDE dan bertanggung jawab atas kerugian yang dialami oleh konsumen yang telah dirugikan atas beredarnya produk merek MICROCIDE karena mengalami kekeliruan dalam menggunakan produk tersebut.

Atas kesamaan merek antara MICROCIDE dan MIKROZID untuk barang yang tidak sejenis dapat juga menimbulkan kerugian pada konsumen, disebabkan karena adanya kesalahan memahami kesamaan pada pokoknya dari merek tersebut. Konsumen yang dirugikan akibat salah dalam menentukan pilihan karena kesalahan persepsi terhadap produk dengan merek yang mempunyai persamaan pada pokoknya antara merek MICROCIDE dan MIKROZID dapat mengakibatkan timbulnya bahaya pada saat dikonsumsi.
Mengenai Pengertian persamaan pada pokoknya sebagaimana ditentukan dalam Penjelasan Pasal 21 ayat (1) UU Merek menentukan sebagai berikut: Yang dimaksud dengan "persamaan pada pokoknya" adalah kemiripan yang disebabkan oleh adanya unsur yang dominan antara Merek yang satu dengan Merek yang lain sehingga menimbulkan kesan adanya persamaan, baik mengenai bentuk, cara penempatan, cara penulisan atau kombinasi antara unsur, maupun persamaan bunyi ucapan, yang terdapat dalam Merek tersebut.

Terkait dengan Perlindungan Hukum terhadap Konsumen terdapat 2 (dua) asas yang dapat digunakan dalam membahas permasalahan ini, yaitu Asas Manfaat dan Asas Keamanan dan Keselamatan Konsumen. Mengenai pengertian kedua asas tersebut terdapat dalam Penjelasan Pasal 2 Undang-undang No. 8 Tahun 1999 tentang Perlindungan Konsumen selanjutnya disingkat UUPK yang menyatakan bahwa:

Perlindungan konsumen diselenggarakan sebagai usaha bersama yang mencakup asas yang relevan dalam pembangunan nasional, yaitu:

1. Asas manfaat dimaksudkan untuk mengamankan bahwa segala upaya dalam penyelenggaraan perlindungan konsumen harus memberikan manfaat yang sebesar-besarnya bagi kepentingan konsumen dan pelaku usaha secara keseluruhan

2. Asas keamanan dan keselamatan konsumen dimaksudkan untuk memberikan jaminan atas keamanan dan keselamatan kepada 
Evelyn Larissa Florentia Wijaya: Perlindungan Hukum Konsumen Atas Kesamaan...

konsumen dalam penggunaan, pemakaian, dan pemanfaatan barang dan/atau jasa yang dikonsumsi atau digunakan

Persamaan merek pada suatu produk itu, akan dapat berdampak pada konsumen ini terlindungi atau tidak. Dalam perkembangannya merek hanyalah sebuah tanda agar konsumen dapat membedakan produk barang/jasa satu dengan yang lainnya. Melalui merek, konsumen lebih mudah mengingat sesuatu yang dibutuhkan, dan dengan cepat dapat menentukan apa yang akan dibelinya (Halim, 2015) Perlindungan terhadap konsumen perlu dilakukan mengingat tujuan perlindungan konsumen sebagaimana terdapat dalam ketentuan Pasal 3 huruf (b), (c) dan (f) UUPK menentukan bahwa:

b. Mengangkat harkat dan martabat konsumen dengan cara menghindarkannya dari akses negatif pemakaian barang dan/atau jasa;

c. Meningkatkan pemberdayaan konsumen dalam memilih, menentukan dan menuntut hakhaknya sebagai konsumen;

f. Meningkatkan kualitas barang dan/atau jasa yang menjamin kelangsungan usaha produksi barang dan/atau jasa, kesehatan, kenyamanan, keamanan dan keselamatan konsumen.

Berdasarkan uraian yang telah dipaparkan pada latar belakang, maka dapat diambil rumusan masalah sebagai berikut yaitu : "Bagaimana perlindungan hukum bagi konsumen akibat kekeliruan dalam menentukan bahan baku dari suatu produk yang mempunyai merek sama pada pokoknya ditinjau dari UndangUndang Nomor 8 Tahun 1999 Tentang Perlindungan Konsumen?"

\section{METODE PENELITIAN}

Tipe penelitian yang digunakan dalam membahas penulisan ini adalah penelitian hukum yuridis normatif, yaitu penelitian yang mana menggunakan Peraturan Perundang - undangan, dan buku-buku bacaan yang didapat dari studi kepustakaan. Pendekatan Masalah dalam kasus ini didekati menggunakan pendekatan Statute Approach dan Conceptual Approach. Statute Approach, yaitu pendekatan masalah yang dilakukan dengan menelaah, mengidentifikasi serta membahas peraturan perundang-undangan yang bersangkutan dengan permasalahan (isu hukum) yang sedang dihadapi. Sedangkan Conceptual Approach, yaitu suatu pendekatan masalah yang didasari oleh ketentuan hukum positif serta dikaitkan dengan pendapat-pendapat para sarjana sebagai landasan hukum pembahasan laporan. Bahan hukum yang digunakan dalam penulisan ini berupa:

a. Bahan hukum Primer

Adalah bahan hukum berupa peraturan perundang- undangan yang meliputi Undang Undang Nomor 8 Tahun 1999 tentang Perlindungan Konsumen

b. Bahan hukum Sekunder

Bahan hukum yang erat hubungannya dengan bahan hukum primer dimana bahan hukum sekunder bersifat menjelaskan bahan hukum primer, yang meliputi buku - buku, literatur - literatur, dan berbagai media cetak yang ada 
kaitannya dengan permasalahan kasus yang hendak dibahas.

\section{HASIL DAN PEMBAHASAN}

Perlindungan hukum bagi konsumen merupakan suatu bentuk upaya yang penting diterapkan untuk menjamin keseimbangan antara Konsumen dan Pelaku Usaha. Keseimbangan perlu dilakukan karena kedua belah pihak saling ada ketergantungan dan saling membutuhkan, artinya tanpa konsumen maka pelaku usaha tidak akan dapat mengembangkan kegiatan usahanya untuk mendapatkan keuntungan sebagaimana diharapkan, demikian juga sebaliknya tanpa Pelaku Usaha maka Konsumen tidak dapat terpenuhi kebutuhan sehariharinya. Berikut bukti ketidakseimbangan antara pelaku usaha dan konsumen ini secara garis besar terkait permasalahan yang terjadi pada proses transaksi elektronik, yaitu :

1. Konsumen tidak dapat langsung mengidentifikasi, melihat, atau menyentuh barang yang akan dipesan;

2. Ketidakjelasan informasi tentang produk yang ditawarkan dan/atau tidak ada kepastian apakah konsumen telah memperoleh berbagai informasi yang layak diketahui, atau yang sepatutnya dibutuhkan untuk mengambil suatu keputusan dalam bertransaksi

3. Tidak jelasnya status subjek hukum, dari pelaku usaha;

4. Tidak ada jaminan keamanan bertransaksi dan privasi serta penjelasan terhadap risiko-risiko yang berkenaan dengan sistem yang digunakan, khususnya dalam hal pembayaran secara elektronik maupun electronic cash;

5. Pembebanan risiko yang tidak berimbang, karena umumnya jual beli di internet, pembayaran telah lunas dilakukan di muka oleh konsumen, sedangkan barang belum tentu diterima atau menyusul kemudian, karena jaminan yang ada adalah jaminan pengiriman barang;

6. Transaksi bersifat lintas batas negara borderless, menimbulkan pertanggan mengenai yuridiksi hukum negara mana yang sepatutnya diberlakukan. (Mukhtar, 2015)

Berbicara masalah perlindungan konsumen dikatakan oleh (Janus Sidabalok, n.d.) (2010, hal. 49) bahwa: "Masalah Perlindungan Konsumen tidak semata-mata merupakan masalah bersama dan masalah nasional, sebab pada dasarnya semua orang adalah konsumen. Perlindungan konsumen adalah melindungi semua orang".

Hak konsumen yang diabaikan oleh pelaku usaha perlu dicermati secara saksama. Beberapa tahun lalu tepatnya tahun 2014 muncul masalah yakni antara merek MICROCIDE dan MIKROZID untuk produk yang tidak sejenis. Perlu diketahui bahwa, Permohonan Kasasi MICROCIDE ditolak oleh Mahkamah Agung berdasarkan Putusan Mahkamah Agung Nomor 653 K/Pdt.Sus-HKI/2014 tanggal 27 Maret 2015. Sebagai dasar pertimbangannya bahwa Merek MICROCIDE tidak memiliki persamaan pada pokoknya atau keseluruhan dengan 
Evelyn Larissa Florentia Wijaya: Perlindungan Hukum Konsumen Atas Kesamaan...

merek MIKROZID. Artinya, pemegang hak MIKROZID sah sebagai pemegang hak atas merek.

Merek MICROCIDE telah terdaftar dalam Daftar Umum Merek pada Direktorat Merek dengan Nomor IDM000077529 tertanggal 8 Januari 2006, yang merupakan perpanjangan daftar Nomor 381233 tertanggal 8 Januari 1996. Pemilik merek MICROCIDE mempunyai hak ekslusif untuk menggunakan sendiri mereknya tersebut atau memberi izin pada pihak lain untuk menggunakannya. Di samping itu, merek MIKROZID merupakan merek yang terkenal dengan reputasi Internasional yang telah dikenal berbagai negara.

Gambar 1. Design Logo MICROCIDE®.

\section{O. MICROCIDE ${ }^{\circledR}$}

Always Safe and Effective ${ }^{(\odot)}$

Gambar 2. Design Logo MIKROZID®.

\section{$\operatorname{mikrozid}^{\circledR}$ Af liquid}

Antara kedua merek tersebut MICROCIDE dan MIKROZID terdapat persamaan pada pokoknya yaitu yang satu dengan huruf "S" dan yang satu dengan huruf " $Z$ ". Keduanya bergerak dalam jenis produk yang berbeda. Produk MICROCIDE berupa zat kimia sediaan farmasi yang dapat diminum dan MIKROZID adalah berupa cairan desinfektan untuk pembasmi kuman yang tidak dapat diminum. Keberadaan produk tersebut di masyarakat sebagai konsumen pada saat menggunakan atau mengkonsumsi produk-produk tersebut.

Keberadaan produk dengan merek yang mirip antara MICROCIDE dan MIKROZID dikhawatirkan dapat merugikan masyarakat yang membeli produk tersebut untuk memenuhi kebutuhannya.

Pelaku usaha wajib menghargai hakhak konsumen, mengikuti standar yang berlaku dan bertanggung jawab atas produk yang dikeluarkannya. Tetapi, dalam melakukan transaksi jual beli elektronik konsumen harus jeli, teliti serta waspada terhadap penawaran yang dilakukan oleh pelaku usaha. Tidak jarang pelaku usaha menawarkan produk yang fiktif, yang dijual murah agar konsumen tertarik (Putra, 2014)

Persamaan pada pokoknya atas produk tersebut yang satu menggunakan huruf "S" dan yang satu menggunakan huruf "Z" dengan penyebutan atau pengucapan dari merek tersebut adalah sama. Hal inilah yang mengakibatkan masyarakat sebagai konsumen bisa terjadi kesalahan dalam memilih produk yang dibutuhkan. Kesalahan dalam memilih merek terhadap produk yang punya merek yang mirip tersebut dapat berdampak pada saat dikonsumsi membahayakan kesehatan konsumen, karena terjadi kekeliruan pada saat menyebutkan mereknya.

Persaingan usaha yang semakin ketat membuat para pelaku usaha 
mengusahakan berbagai cara agar produknya dapat laku di pasaran. Akibatnya banyak pelaku usaha yang menggunakan cara instant dengan membonceng ketenaran merek terkenal, baik untuk barang yang sejenis maupun tidak sejenis (Valerie \& Hotman, 2019)

Dalam dunia persaingan usaha memang tidak dapat lagi dibatasi masuknya produk-produk dari luar negeri ke Indonesia karena fenomena tersebut sebetulnya sudah jauh di prediksi oleh Kanichi Ohmar yang menyatakan "bahwa pada masa mendatang dunia tidak lagi bisa dibatasi oleh apapun juga" (Delima, 2018)

Tindakan- tindakan peniruan merek yang sama pada pokoknya yang sudah dikenal lebih dahulu oleh masyarakat dapat dikategorikan sebagai persaingan curang (unfair competition) yang dilandasi dengan itikad tidak baik yang dapat merugikan konsumen (Suryadirja, 2012)

Bahaya mengkonsumsi bahan kimia yakni zat MIKROZID merupakan dampak buruk hasil dari reaksi zat beracun yang jika masuk ke dalam tubuh menyebabkan kerusakan organ internal. Bahan kimia berbahaya telah ada dan digunakan dalam kehidupan sehari-hari yang jika dipakai dengan skala kecil atau besar dan dikonsumsi secara teratur. Maka, di masa depan dapat menyebabkan beberapa hal negatif sebagai berikut: menyebabkan iritasi, korosif, alergi, menyebabkan sulit bernapas, menyebabkan keracunan sistemik, kanker, kerusakan atau kelainan, menyebabkan pneumoconiosis dan lain sebagainya.

Merek adalah salah satu atribut yang penting dari sebuah produk, dimana merek suatu produk dapat memberikan nilai tambah bagi produk yang dihasilkan. Dengan adanya merek, konsumen dapat membedakan produk satu dengan yang lain yang diproduksi oleh suatu perusahaan, apalagi jika produk yang dihasilkan adalah produk barang dan/atau jasa yang sejenis. Oleh karena itu pemilik merek akan melakukan segala upaya yang dibutuhkan untuk melindungi mereknya agar tidak ditiru oleh pihak lain. Mengenai pengertian merek terdapat dalam Pasal 1 angka (1) UU Merek sebagai berikut:

Merek adalah tanda yang dapat ditampilkan secara grafis berupa gambar, logo, nama, kata, huruf, angka, susunan warna, dalam bentuk 2 (dua) dimensi dan/atau 3 (tiga) dimensi, suara, hologram, atau kombinasi dari 2 (dua) atau lebih unsur tersebut untuk membedakan barang dan/atau jasa yang diproduksi oleh orang atau badan hukum dalam kegiatan perdagangan barang dan/atau jasa.

Sedangkan menurut (Rahmi Jened, 2000) Merek adalah "Tanda untuk mengidentifikasi asal barang dan jasa (an indication of origin) dari suatu perusahaan dengan barang dan/atau jasa perusahaan lain. melalui merek, pengusaha dapat menjaga dan memberikan jaminan akan kualitas ( $a$ guarantee of quality). Merek sebagai sarana pemasaran dan periklanan yang memberikan suatu tingkat informasi 
Evelyn Larissa Florentia Wijaya: Perlindungan Hukum Konsumen Atas Kesamaan...

tertentu kepada konsumen mengenai barang dan/atau jasa yang dihasilkan pengusaha.

Memasuki realita pasar, merek hadir dengan dua fungsi utama: sebagai tanda pembeda dan sebagai penunjuk asal barang. Kedua fungsi tersebut dijalankan secara paralel dan setara. Artinya, fungsi yang satu tidak melampaui peran yang lain dan secara fungsi tidak saling mengabaikan atau menegaskan. (Wijaya, 2018). Merek harus memiliki daya pembeda dari merek-merek lainnya yang diharapkan dapat menjadi keunikan yang mencerminkan orisinilitas produk tersebut (Perdana, 2017)

Hak atas merek itu diperoleh apabila telah melakukan pendaftaran sesuai dengan ketentuan dimaksud dalam Pasal 1 angka 5 UU Merek, yang menentukan sebagai berikut: Hak atas Merek adalah hak ekslusif yang diberikan oleh negara kepada pemilik Merek yang terdaftar untuk jangka waktu tertentu dengan menggunakan sendiri Merek tersebut atau memberikan izin kepada pihak lain untuk menggunakannya.

Menurut (Rachmadi Usman, 2000) mengatakan: "Hak khusus memakai merek ini berfungsi sebagai suatu monopoli, hanya berlaku untuk barang atau jasa tertentu. Karena suatu merek memberi hak khusus atau hak mutlak pada yang bersangkutan, hak itu dapat dipertahankan kepada siapapun". Dengan adanya hak ekslusif atau hak khusus tersebut, orang lain dilarang untuk menggunakan merek yang terdaftar untuk barang dan/atau jasa sejenis dan juga memberikan perlindungan kepada pemilik merek yang beritikad baik, kecuali sebelumnya mendapat izin dari pemilik terdaftar. Jika hal ini dilanggar, pengguna merek terdaftar tersebut dapat dituntut secara perdata maupun pidana oleh pemilik merek terdaftar.

Perlu diketahui bahwa, Permohonan Kasasi MICROCIDE ditolak oleh Mahkamah Agung berdasarkan Putusan Mahkamah Agung Nomor 653 K/Pdt.SusHKI/2014 tanggal 27 Maret 2015 diantaranya : Putusan Mahkamah Agung Nomor 653 K/Pdt.Sus-HKI/2014 tanggal 27 Maret 2015. Sebagai dasar pertimbangan bahwa Merek MICROCIDE tidak memiliki persamaan pada pokoknya atau keseluruhan dengan merek MIKROZID. Putusan MA tersebut berdasar pada belum adanya Peraturan Pelaksana atas pelanggaran merek yang sama pada pokoknya untuk barang yang tidak sejenis sebagaimana tertuang dalam Pasal 21 UU Merek yang menentukan sebagai berikut:

Ayat (1) Permohonan ditolak jika Merek tersebut mempunyai persamaan pada pokoknya atau keseluruhan dengan:

c. Merek terdaftar milik pihak lain atau dimohonkan lebih dahulu oleh pihak lain untuk barang dan/atau jasa sejenis

d. Merek terkenal milik pihak lain untuk barang dan/atau jasa sejenis

e. Merek terkenal milik pihak lain untuk barang dan/atau jasa tidak sejenis yang memenuhi persyaratan tertentu

f. Indikasi geografis terdaftar. 
Ayat (4) Ketentuan lebih lanjut mengenai penolakan permohonan. Merek sebagaimana dimaksud pada ayat (1) huruf a sampai dengan huruf $\mathrm{c}$ diatur dengan Peraturan Menteri.

Belum adanya Peraturan Pelaksana tersebut dapat mengakibatkan Penggunaan Merek yang sama pada pokoknya untuk barang yang tidak sejenis dapat merugikan Pemilik Merek dan Masyarakat sebagai Konsumen. Pemilik Merek juga dirugikan karena pemboncengan merek yang sudah terkenal dan masyarakat konsumen akan terkecoh atas keberadaan merek yang sama pada pokoknya tersebut untuk barang yang tidak sejenis.

Pelaku usaha MIKROZID telah menggunakan merek yang sama pada pokoknya dengan Pelaku usaha MICROCIDE dan bertanggung jawab atas kerugian yang dialami oleh konsumen yang telah dirugikan atas beredarnya produk merek MICROCIDE karena mengalami kekeliruan dalam menggunakan produk tersebut.

Mengenai Pengertian persamaan pada pokoknya sebagaimana ditentukan dalam Penjelasan Pasal 21 ayat (1) UU Merek menentukan sebagai berikut:

Yang dimaksud dengan "persamaan pada pokoknya" adalah kemiripan yang disebabkan oleh adanya unsur yang dominan antara Merek yang satu dengan Merek yang lain sehingga menimbulkan kesan adanya persamaan, baik mengenai bentuk, cara penempatan, cara penulisan atau kombinasi antara unsur, maupun persamaan bunyi ucapan, yang terdapat dalam Merek tersebut.
Atas kesamaan merek antara MICROCIDE dan MIKROZID untuk barang yang tidak sejenis dapat juga menimbulkan kerugian pada konsumen, disebabkan karena adanya kesalahan memahami kesamaan pada pokoknya dari merek tersebut. Konsumen yang dirugikan akibat salah dalam menentukan pilihan karena kesalahan presepsi terhadap produk dengan merek yang mempunyai persamaan pada pokoknya antara merek MICROCIDE dan MIKROZID dapat mengakibatkan timbulnya bahaya pada saat dikonsumsi.

Merek yang ada pada produk merupakan suatu informasi bagi konsumen. Kesalahan dalam memahami informasi tentang merek MICROCIDE dan MIKROZID dengan kandungan yang berbeda satu dengan yang lainnya dapat merugikan konsumen. Mengenai Hak Konsumen dalam hal mendapatkan informasi diatur dalam Pasal 4 huruf $\mathrm{c}$ UUPK yaitu : Hak atas informasi yang benar, jelas dan jujur mengenai kondisi dan jaminan barang dan/jasa”.

Apabila dikaitkan dengan ketentuan Pasal 1 angka 5 UU Merek dapat dikatakan bahwa baik MICROCIDE dan MIKROZID sama-sama telah terdaftar di Indonesia, sehingga keduanya disebut sebagai Pemilik Merek. Hanya saja perlu diperhatikan diantara kedua pemilik merek tersebut apakah ada itikad baik pada saat mendaftarkan sehingga merek keduanya ada kesamaan pada pokoknya. Meskipun untuk produk yang berbeda.

Terkait dengan adanya persamaan pada pokoknya atas merek yang dimiliki 
Evelyn Larissa Florentia Wijaya: Perlindungan Hukum Konsumen Atas Kesamaan...

Pelaku Usaha MIKROZID menunjukkan bahwa dalam hal ini Pelaku Usaha tersebut telah melakukan itikad tidak baik pada saat mendaftarkan mereknya di Indonesia. Yang dimaksud dengan Pemohon yang beritikad tidak baik terdapat dalam Penjelasan Pasal 21 ayat

(3) UU Merek sebagai berikut:

"Pemohon yang beritikad tidak baik" adalah Pemohon yang patut diduga dalam mendaftarkan Mereknya memiliki niat untuk meniru, menjiplak, atau mengikuti Merek pihak lain demi kepentingan usahanya menimbulkan kondisi persaingan usaha tidak sehat, mengoceh, atau menyesatkan konsumen".

Terkait dengan perlindungan kepada konsumen, pemilik merek MICROCIDE dan MIKROZID disebut sebagai Pelaku Usaha. Hal ini sesuai dengan ketentuan dalam Pasal 1 angka (3) UUPK menentukan sebagai berikut:

Pelaku Usaha adalah setiap orang perseorangan atau badan usaha, baik berbentuk badan hukum maupun bukan badan hukum yang didirikan dan berkedudukan atau melakukan kegiatan dalam wilayah hukum negara Republik Indonesia, baik sendiri maupun bersama-sama melalui perjanjian menyelenggarakan kegiatan usaha dalam berbagai bidang ekonomi.

Sedangkan yang disebut Konsumen dalam hal ini adalah masyarakat yang mengkonsumsi atau menggunakan produk tersebut, dan tidak untuk dijual kembali sebagaimana diatur dalam Pasal 1 angka (2) UUPK sebagai berikut : Konsumen adalah setiap orang pemakai barang dan/atau jasa yang tersedia dalam masyarakat, baik bagi kepentingan diri sendiri, keluarga, orang lain, maupun makhluk hidup lain dan tidak untuk diperdagangkan. keduanya memiliki hak dan kewajiban serta hal-hal yang dilarang untuk dilakukan.

Sebagai Pelaku Usaha, pemilik produk MIKROZID seharusnya memenuhi kewajiban-kewajibannya sebagaimana diatur dalam Pasal 7 huruf a UUPK yaitu: Beritikad baik dalam melakukan kegiatan usahanya. Selain itu Pelaku Usaha MIKROZID dilarang memproduksi dan/atau memperdagangkan barang yang melanggar ketentuan perundang-undangan sebagaimana diatur dalam Pasal 8 ayat 1 huruf a UUPK yang menentukan sebagai berikut: Tidak memenuhi atau tidak sesuai dengan standar yang dipersyaratkan dan ketentuan perundang-undangan.

Peniruan merek yang dilakukan oleh MIKROZID mengakibatkan konsumen dirugikan, sehingga pelaku usaha MIKROZID bertanggung gugat terhadap kerugian yang dialami konsumen tersebut.

\section{SIMPULAN}

Berdasarkan uraian pembahasan yang telah diuraikan pada bab sebelumnya, dapat ditarik kesimpulan bahwa antara merek MICROCIDE dan MIKROZID merupakan persamaan pada pokoknya untuk barang yang tidak sejenis. Akibat dari adanya merek yang mempunyai persamaan pada pokoknya tersebut dapat menimbulkan kerugian bagi konsumen dengan uraian sebagai berikut Dua produk tersebut merupakan barang yang tidak 
sejenis, untuk merek MICROCIDE merupakan zat kimia sediaan farmasi yang tidak berbahaya untuk dikonsumsi, sedangkan merek MIKROZID merupakan cairan desinfektan untuk pembasmi kuman adalah jenis barang yang berbahaya jika dikonsumsi. Terkait dengan kedua merek tersebut. Apabila konsumen salah memilih akibatnya akan merugikan bahkan dapat membahayakan konsumen. Selain itu, Pelaku Usaha MIKROZID tidak melakukan perbuatan yang curang karena Permohonan Kasasi MICROCIDE ditolak oleh Mahkamah Agung berdasarkan Putusan Mahkamah Agung Nomor 653 K/Pdt.Sus-HKI/2014 tanggal 27 Maret 2015, artinya pemegang hak MIKROZID sah sebagai pemegang hak atas merek. Berdasarkan Putusan MA tersebut, pemegang hak merek MIKROZID bebas mengedarkan barangnya di pasaran. Juga terhadap Putusan Mahkamah Agung Nomor 653 K/Pdt.Sus-HKI/2014 tanggal 27 Maret 2015 menentukan bahwa tidak ada permasalahan terkait dengan kedua merek tersebut, dikarenakan dalam UndangUndang No. 10 tahun 2016 tentang Merek dan Indikasi Geografis belum ada Peraturan Pelaksana untuk Merek yang sama pada pokoknya untuk barang yang tidak sejenis. Akibat belum adanya Peraturan Pelaksana tersebut menyebabkan tidak dipenuhinya hak konsumen yaitu Hak atas kenyamanan, keamanan, dan keselamatan dalam mengkonsumsi barang dan/atau jasa dan Hak atas informasi yang benar, jelas dan jujur mengenai kondisi dan jaminan barang dan/atau jasa.
Berdasarkan kesimpulan tersebut, maka saran yang dapat diberikan adalah: Pertama, kepada Pemerintah, dalam hal ini Badan Pengawas Obat dan makanan (BPOM) sebagai lembaga pengawas terhadap produk barang yang beredar harus tegas dan teliti agar layak edar dan memberikan sanksi yang tegas terhadap pelanggaran yang terjadi. Kedua, Hendaknya Dirjen HKI meneliti, memilih dan membandingkan logo dan tulisantulisan dari suatu merek yang didaftarkan dengan melakukan pengumuman tertulis, menempelkan contoh-contoh logo dan tulisan tentang merek yang akan didaftarkan tersebut. Ketiga, Peraturan Pemerintah sebagai Peraturan Pelaksanaan dari Pasal 21 UU Merek yang terkait dengan barang yang tidak sejenis segera dibuat agar melindungi kepentingan Konsumen dan Pelaku Usaha itu sendiri.

\section{DAFTAR PUSTAKA}

Ahmadi Miru. (n.d.). Prinsip-Prinsip Perlindungan Hukum Bagi Konsumen di Indonesia.

Delima, E. (2018). Perlindungan Konsumen Berdasarkan UndangUndang Nomor 8 Tahun 1999 Terhadap Merek Tas Palsu Oleh Pelaku Usaha Di Kota Pekanbaru. JOM Fakultas Hukum Nomor 1, V, 9.

Endang Sri Wahyuni. (n.d.). Hukum Perlindungan Konsumen.

Halim, L. (2015). Perlindungan Merek dan Pengaruhnya Bagi Perlindungan Konsumen. Lex Privatum No 6, V, 1. 
Evelyn Larissa Florentia Wijaya: Perlindungan Hukum Konsumen Atas Kesamaan...

Janus Sidabalok. (n.d.). Hukum Perlindungan Konsumen di Indonesia.

Mukhtar, J. (2015). Perlindungan Hukum Terhadap Konsumen dalam Transaksi Online. Serambi Hukum No 2, 8, 94.

Perdana, K. (2017). Kelemahan UndangUndang Merek Dalam Hal Pendaftaran Merek. Privat Law, V.

Permatasari, C. (2008). Dugaan Persaingan Usaha Tidak Sehat Yang Dilakukan Oleh PerusahaanPerusahaan Farmasi Di Indonesia Dalam Penetapan Obat Generik. 14.

Purwadarninta. (n.d.). Kamus Besar Bahasa Indonesia.

Putra, S. (2014). Perlindungan Hukum Terhadap Konsumen Dalam Transaksi Jual-Beli Melalui ECommerce. Jurnal Ilmu Hukum No 2, 4, 297.

Rachmadi Usman. (2000). Hukum Hak atas Kekayaan Intelektual, Perlindungan dan Dimensi Hukumnya di Indonesia.
Rahmi Jened. (2000). Implikasi Persetujuan TRIP's Bagi Perlindungan Merek di Indonesia.

Suryadirja, I. (2012). Perlindungan Merek Terkenal Kemasan Produk Tiga Dimensi. Jurnal Hak Kekayaan Intelektual, 1, 23.

Valerie, N., \& Hotman, E. (2019). Perlindungan Hukum Terhadap Merek Terkenal Christian Dior Ditinjau Dari Konsep Trademark Dilution. Jurnal Cendekiawan Hukum No.2, 4, 2.

Wijaya, W. (2018). Analisis Kekuatan Unsur Itikad Baik Pada Pelaksanaan Pendaftaran Merek Di Indonesia (Studi Kasus Putusan Mahkamah Agung Nomor 364k/Pdt.SusHki/2014) Berdasarkan UndangUndang Nomor 20 Tahun 2016. Jurnal Hukum Adigama No. 1, Vol. 1,15 .

Undang- Undang Nomor 8 Tahun 1999 Tentang Perlindungan Konsumen

Undang-Undang Nomor 10 Tahun 2016 Tentang Merek dan Indikasi Geografis . 